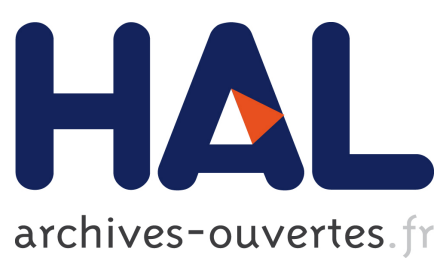

\title{
The experience matters: participation-related rewards increase the success chances of crowdfunding campaigns Tobias Regner, Paolo Crosetto
}

\section{To cite this version:}

Tobias Regner, Paolo Crosetto. The experience matters: participation-related rewards increase the success chances of crowdfunding campaigns. Working paper GAEL n 04/2017. 2017.

\section{HAL Id: hal-01527150 \\ https://hal.archives-ouvertes.fr/hal-01527150}

Submitted on 24 May 2017

HAL is a multi-disciplinary open access archive for the deposit and dissemination of scientific research documents, whether they are published or not. The documents may come from teaching and research institutions in France or abroad, or from public or private research centers.
L'archive ouverte pluridisciplinaire $\mathbf{H A L}$, est destinée au dépôt et à la diffusion de documents scientifiques de niveau recherche, publiés ou non, émanant des établissements d'enseignement et de recherche français ou étrangers, des laboratoires publics ou privés. 


\section{GAEL}

Grenoble Applied Economic Laboratory

Consumption - Energy - Innovation

\section{The experience matters}

\section{Participation-related rewards increase the success chances of crowdfunding campaigns}

\section{Tobias Regner \\ Paolo Crosetto}

May 2017

JEL : L26, D03, G 32 


\title{
The experience matters: participation-related rewards increase the success chances of crowdfunding campaigns
}

\author{
Tobias Regner*; Paolo Crosetto * \\ * GAEL, INRA, CNRS, Grenoble INP, Univ. Grenoble-Alpes, 38000, Grenoble, France \\ - University of Jena, Jena, Germany
}

\begin{abstract}
Crowdfunding recently emerged as an alternative funding channel for start-ups, creative artists and social endeavors. On specialized web platforms, project creators ask the crowd for support and provide in return a set of rewards, modulated according to the amount of support pledged. Our study investigates the role of self- and social-image enhancing rewards in determining project success. Using data from 346 projects hosted by Startnext, the biggest crowdfunding platform in Germany, we show that providing higher shares of reward levels that let pledgers participate in and experience the project is correlated with project success.
\end{abstract}

JEL classifications: L26, D03, G32

Keywords: crowdfunding, entrepreneurial finance, donations, reward levels, identity, self-image, social-image

\section{Introduction}

Reward-based crowdfunding recently emerged as an alternative funding channel for entrepreneurs, creative artists and social projects. Beside the option to simply donate money, project creators often provide rewards: products or services promised in exchange for pledging a specific amount. Projects differ in the number, nature, and monetary requirements of the reward levels offered. A typical project features 'cheap' levels delivering a thank-you note or small gadget, 'medium' levels providing the full product, invitations to events or more elaborated gadgets (notably merchandising), and 'expensive' levels with exclusive or all-comprehensive offers. Levels are usually nested, with the more expensive ones including all rewards of cheaper ones, plus some extra.

Project-level determinants of crowdfunding projects have already been studied and some robust stylized facts emerged: quality signals like the project's communication with pledgers [Mollick, 2014, Kromidha and Robson, 2016, Gafni et al., 2017] or the creator's social capital [Mollick, 2014, Colombo et al., 2015] increase chances of success. However, little is known about the impact of the reward

\footnotetext{
*Corresponding author (tobias.regner@uni-jena.de). Both authors contributed equally to this research project, the order of the authors was randomized.

We are grateful to Startnext, especially Anna Theil, for providing the data and helpful discussions. We would like to thank audiences in Mannheim and Jena for feedback. Daniel Meyer and Javier Changoluisa provided excellent research assistance. Tobias Regner gratefully acknowledges support by Deutsche Forschungsgemeinschaft (DFG, German Research Foundation) project number 628902.
} 
structure. While Frydrych et al. [2014] find no correlation between the number of reward levels and project success, Simons et al. [2017] provide evidence that the cognitive bias for the middle option affects choices among rewards.

In this paper we look beyond such quantitative/design aspects and into the role played by the type of reward in mobilizing pledgers. We categorize reward levels based on the concept of identity [Tajfel and Turner, 1979], introduced by Akerlof and Kranton [2000] into economic modeling: behavior in line with one's identity results in positive utility, while behavior in contrasts with it has negative effects. The role of identity-building is crucial in crowdfunding. Gerber et al. [2012] find that funders are motivated by feelings of connectedness to a like-minded community in interviews at three crowdfunding platforms and Belleflamme et al. [2014] stress that "the crowd must identify themselves as such."

We hypothesize that such an identity/community feeling of crowdfunders can be supported by rewards that strengthen the relationship between the crowd and the project creator. Rewards can enhance the self-image of the pledger as a member of the community. Self-image-enhancing rewards are meant for the pledger only. Examples are postcards or individualized services/products. Projects can also use their reward structure to create appeal for funders with social-image concerns [Bénabou and Tirole, 2005, Ellingsen and Johannesson, 2008, Andreoni and Bernheim, 2009]. Supporting new products/services - and showing this to others - boosts the social reputation of some individuals and, in turn, translates into an increased willingness to spend. Examples of social-image rewards are special thanks at the end of a movie or being mentioned as donor on the project web site. Rewards levels can also cater to both social- and self-image at the same time. This is the case of invitations to special project-related events (e.g. a meet\&greet) or clothing conveying the community membership (t-shirts, bags, etc.).

We use data from Startnext to assess the role of reward levels and types in project success. Startnext is the biggest reward-based crowdfunding platform in Germany, with 37 millions $€$ raised by January 2017. ${ }^{1}$ We merge individual pledge data and product characteristics obtained from Startnext with a manual categorization of the self- and social-image aspects of reward levels. Our final dataset consists of 346 projects (186 successful), for a total of 785 thousand $€$ raised.

Results show that projects offering a higher number of rewards appealing to the crowd's identity, specifically offering ways for pledgers to actively participate in the project, have a positive impact on success.

\section{Data Set}

We obtained a fully anonymized database dump from Startnext. Startnext projects have a page on the platform featuring the funding target, duration time, a text description, a pitch video and pictures. All projects have a blog for updates and to communicate with the public. At any moment, the page displays the remaining time, the current funding level (as a \% of the target) and number of supporters. Project creators can choose funding durations of 5 to 90 days.

\footnotetext{
${ }^{1}$ Startnext employs the threshold pledge model, as Kickstarter. If pledges reach the target amount by the deadline, the project is funded and pledges are paid; else, no transaction takes place.
} 
The data, described in more detail in Crosetto and Regner [2017], contain all transactions on the platform from the date of its launch in October 2010 to February 10th, 2014. The dataset consists of 2,713 projects. Out of those, 2,254 got enough fans to reach the funding phase ${ }^{2}$ and 1,139 were successfully funded. For each project we have the following variables (averages in parentheses): funding duration (54 days), target amount $(6,194 €)$, whether the project has been featured on Startnext's home page $(8.3 \%)$, number of words (half a page), videos (1.1), images (7.6) on the project page or blog, number of entries on the project blog (4), its number of fans (79.6) and the projects' category. The most popular project categories are movies (31.6\%), music $(25 \%)$, event (11.6\%) and cultural education $(11.1 \%)$.

The reward level structure was not part of the data dump. We hence manually gathered information from the individual web pages of 346 randomly picked individual projects - roughly $15 \%$ of the total sample. For each project belonging to our random sample, we collected all the reward levels and the corresponding amounts needed to unlock the reward. We then categorized the reward levels with respect to the visibility of the pledger's support: rewards can appeal to the pledgers' self- and/or socialimage concerns. Levels that facilitate the pledgers' identification with the project are categorized as self-image only. We require them to help pledgers remember being part of the project, to have limited public visibility, and to be tangible/physical. Examples are postcards or stickers. The announcement of the pledger's name in a situation with public exposure (e.g., being mentioned as a donor in the booklet/credits, on a social media platform, the project web site) is regarded as a social-image only reward. Some reward levels have both self- and social-image appeal. The nature of the reward itself can nonetheless vary within this category. Project merchandising (e.g., t-shirts, bags) facilitates pledgers' identification with the project but since it also conveys the pledgers' support to the public we treat it as having both self- and social-image characteristics. Being publicly part of the project, for instance, as an extra in the movie, after show backstage access, a meet\&greet, also relates to self- as well as socialimage, but with a different type of involvement, as it gives the pledger an enhanced sense of community and participation.

Thus, we base our analysis around four main types of rewards: social-image only, self-image only, and two types of combined self- and social-image rewards: active participation in the project and merchandising. For each of these types we compute its relative importance among all reward levels of a project. Self-image only rewards account for $36 \%$ of all levels, participation for $24 \%$, social-image only $11 \%$ and merchandising $10 \%{ }^{3}$

\section{Results}

Table 1 reports marginal effects of four different regression specifications. Column 1 reports a probit regression of project success on its main determinants. It is run on the full Startnext dump of 2,254 projects and is given for reference. Columns 2 to 4 report probit regressions on the reward levels sample of 346 projects. Column 2 uses the same specification of column 1, without any reference to reward

\footnotetext{
${ }^{2}$ Projects have to reach a minimum level of fan support to go public on the website. For details see Crosetto and Regner [2017].

${ }^{3}$ This classification does not cover all levels, since some do not entail any actual reward and are outright donations. Others offer unrelated services with no self- or social-image impact.
} 
levels. Column 3 provides a supply-side analysis of the impact on project success. Variables reflect the share of each type of level, irrespective of the amount of pledgers that chose them. Column 4 includes instead a demand-side analysis. Variables reflect the share of pledges gone to levels belonging to each category; the relative success (or failure) of each level is thus taken into account. However, levels requiring higher amounts of money have by construction a bigger impact on the likelihood of success, conditional on being chosen. Columns 3 and 4 hence complement each other. All columns include the full set of category dummies (music, games, technology, etc.) as control. All results are robust to the exclusion of category dummies.

\begin{tabular}{|c|c|c|c|c|c|c|c|c|}
\hline & \multirow{2}{*}{\multicolumn{2}{|c|}{$\frac{\text { Full Startnext sample }}{\text { Project success }}$}} & \multirow{2}{*}{\multicolumn{2}{|c|}{$\frac{\text { Project level analysis }}{\text { Project success }}$}} & \multirow{2}{*}{\multicolumn{2}{|c|}{$\begin{array}{l}\text { Offered levels } \\
\text { Project success }\end{array}$}} & \multicolumn{2}{|c|}{ Chosen levels } \\
\hline & & & & & & & \multicolumn{2}{|c|}{ Project success } \\
\hline & coeff. & st.err & coeff. & st.err & coeff. & st.err & coeff. & st.err \\
\hline Funding Duration & $-0.0029^{* * *}$ & $(.0005)$ & -0.00220 & $(0.00137)$ & $-0.00242^{*}$ & $(0.00139)$ & -0.00237 & $(0.00145)$ \\
\hline Target amount (1000€) & $-0.1075^{* * *}$ & $(.0137)$ & $-0.0958^{* * *}$ & $(0.0179)$ & $-0.0985^{* * *}$ & $(0.0184)$ & $-0.0960^{* * *}$ & $(0.0185)$ \\
\hline Total number of fans & $0.0091^{* * *}$ & $(.001)$ & $0.00930^{* * *}$ & $(0.00153)$ & $0.00925^{* * *}$ & $(0.00158)$ & $0.00851^{* * *}$ & $(0.00156)$ \\
\hline Featured on main page & $0.4741^{* * *}$ & $(.1012)$ & 0.291 & $(0.229)$ & 0.315 & $(0.227)$ & 0.323 & $(0.229)$ \\
\hline Word count $(100)$ & 0.0068 & $(.0045)$ & -0.00103 & $(0.0120)$ & -0.00244 & $(0.0122)$ & -0.00353 & $(0.0123)$ \\
\hline Video count & $0.0213^{* *}$ & $(.0085)$ & 0.0477 & $(0.0315)$ & 0.0462 & $(0.0322)$ & 0.0532 & $(0.0327)$ \\
\hline Image count & 0.0019 & $(.0026)$ & $0.0234^{* * *}$ & $(0.00812)$ & $0.0229^{* * *}$ & $(0.00824)$ & $0.0223^{* * *}$ & $(0.00820)$ \\
\hline Blog entries & $0.029^{* * *}$ & $(.0042)$ & $0.0350^{* * *}$ & $(0.0102)$ & $0.0377^{* * *}$ & $(0.0106)$ & $0.0333^{* * *}$ & $(0.0104)$ \\
\hline \multicolumn{9}{|l|}{ Analysis of reward levels } \\
\hline Number of reward levels & & & -0.00487 & $(0.00873)$ & -0.00369 & $(0.00879)$ & -0.00499 & $(0.00890)$ \\
\hline \multicolumn{9}{|l|}{ Offered levels } \\
\hline Self image only & & & & & 0.00332 & $(0.00257)$ & & \\
\hline Social image only & & & & & 0.00263 & $(0.00167)$ & & \\
\hline Self+social: participation & & & & & $0.00361^{* *}$ & $(0.00179)$ & & \\
\hline Self+social: merchandising & & & & & 0.00161 & $(0.00212)$ & & \\
\hline \multicolumn{9}{|l|}{ Chosen levels } \\
\hline Self image only & & & & & & & 0.000786 & $(0.00206)$ \\
\hline Social image only & & & & & & & 0.000176 & $(0.00124)$ \\
\hline Self+social: participation & & & & & & & $0.00339^{* *}$ & $(0.00156)$ \\
\hline Self+social: merchandising & & & & & & & 0.000959 & $(0.00205)$ \\
\hline$N$ & \multicolumn{2}{|c|}{2,254} & \multicolumn{2}{|c|}{346} & \multicolumn{2}{|c|}{346} & \multicolumn{2}{|c|}{$336^{a}$} \\
\hline pseudo- $R^{2}$ & \multicolumn{2}{|c|}{0.336} & \multicolumn{2}{|c|}{0.341} & \multicolumn{2}{|c|}{0.353} & \multicolumn{2}{|c|}{0.345} \\
\hline
\end{tabular}

Table 1: Marginal effects for the reference dataset and different specifications on the reward-level dataset

Columns 1 and 2 replicate the main stylized facts from the literature. For the whole Startnext database (column 1) success is more likely for less ambitious projects with shorter funding durations; for projects that invest in communication of any form especially videos and news updates via the blog; the more fans a project attracts; for projects featured on the Startnext home page. When looking at the category dummies (not shown), music projects are significantly more likely to succeed, while invention, literature, design and games projects less so.

Most of these findings translate to our smaller sample of 346 projects (column 2). Notable exceptions are image count, which plays a role in the restricted but not in the larger sample; and video count and recommendation by Startnext that, though showing the same sign and similar magnitude, do not reach significance in the smaller sample.

Adding our self- and social-image categorization reveals that increasing the share of participation rewards is correlated with project success, all other determinants staying the same. This is true both when looking from the supply side - including the share of offered reward levels entailing participation in the project - and from the demand side - taking into account the actual choices of pledgers. 
Results suggest that giving the crowd more opportunities to be part of the project helps eliciting more crowd support and increases the probability of project success. In particular, since the average project has about 10 reward levels, out of which 2.5 are participation rewards, adding one participation reward is predicted to increase the likelihood of success by $3 \%$.

\section{Discussion}

What determines the success of campaigns in reward-based crowdfunding? Previously, studies have identified the importance of conveying the quality of a project and its respective creator. Communication with the crowd has repeatedly been found to influence funding success [Mollick, 2014, Kromidha and Robson, 2016, Gafni et al., 2017] and also the size of the project creator's personal network matters [Mollick, 2014, Colombo et al., 2015].

What else can project creators do to increase their chances of funding success? We find that the structure of the reward levels is another important channel for the creator to attract potential pledgers. Projects that offer a higher share of reward levels providing enhanced participation possibilities have a higher probability of success. This includes being an extra in the movie, after show backstage access or a meet\&greet with the creator of the project. This result is robust to controlling for the fact that those reward levels are usually the most expensive, thus contributing per se more to project success.

Our finding further supports the intuition that one of the key tasks of crowdfunding project creators is to create a feeling of community around the project, and sustaining this feeling during the whole campaign [Gerber et al., 2012, Belleflamme et al., 2014]. We provide evidence that pledgers' identity concerns can be mobilized via the reward level structure. While self-/social-image concerns are also triggered by other reward level types (public credits for support, merchandising or simply an item that facilitates remembering support), we only find evidence for an effect when pledgers participate in the ongoing crowd effort in a more literal sense. It seems that it is more the actual experience of being part of the project than showing support (on a bag or t-shirt) or being publicly mentioned as a supporter that has a not negligible impact on the likelihood of success.

\section{References}

George A Akerlof and Rachel E Kranton. Economics and identity. Quarterly Journal of Economics, 115(3): 715-753, 2000.

James Andreoni and B Douglas Bernheim. Social image and the 50-50 norm: A theoretical and experimental analysis of audience effects. Econometrica, 77(5):1607-1636, 2009.

Paul Belleflamme, Thomas Lambert, and Armin Schwienbacher. Crowdfunding: Tapping the right crowd. Journal of Business Venturing, 29:585-609, 2014.

Roland Bénabou and Jean Tirole. Incentives and prosocial behavior. American Economic Review, 96(5): 1652-1678, 2005. 
Massimo G. Colombo, Chiara Franzoni, and Cristina Rossi-Lamastra. Internal social capital and the attraction of early contributions in crowdfunding. Entrepreneurship Theory and Practice, 39(1):75-100, 2015.

Paolo Crosetto and Tobias Regner. It's never too late: funding dynamics and self-pledges in crowdfunding. Working Papers 2017-06, Grenoble Applied Economics Laboratory (GAEL), 2017.

Tore Ellingsen and Magnus Johannesson. Pride and prejudice: The human side of incentive theory. American Economic Review, 98(3):990-1008, 2008.

Denis Frydrych, Adam J Bock, Tony Kinder, and Benjamin Koeck. Exploring entrepreneurial legitimacy in reward-based crowdfunding. Venture Capital, 16(3):247-269, 2014.

Hadar Gafni, Dan Marom, and Orly Sade. Are the life and death of an early stage venture indeed in the power of the tongue? lessons from online crowdfunding pitches. 2017.

Elizabeth M Gerber, Julie S Hui, and Pei-Yi Kuo. Crowdfunding: Why people are motivated to post and fund projects on crowdfunding platforms. In Proceedings of the International Workshop on Design, Influence, and Social Technologies: Techniques, Impacts and Ethics, volume 2, page 11, 2012.

Endrit Kromidha and Paul Robson. Social identity and signalling success factors in online crowdfunding. Entrepreneurship \& Regional Development, 28(9-10):605-629, 2016.

Ethan Mollick. The dynamics of crowdfunding: An exploratory study. Journal of Business Venturing, 29 (1):1-16, 2014.

Alexander Simons, Markus Weinmann, Matthias Tietz, and Jan vom Brocke. Which reward should i choose? preliminary evidence for the middle-option bias in reward-based crowdfunding. In Proceedings of the 50th Hawaii International Conference on System Sciences, 2017.

Henri Tajfel and John C Turner. An integrative theory of intergroup conflict. The social psychology of intergroup relations, 33(47):74, 1979. 